\title{
Feeling Seen: Aboriginal and Torres Strait Islander LGBTIQ+ Peoples, (In)Visibility, and Social-Media Assemblages
}

\author{
Andrew Farrell \\ Department of Indigenous Studies, Macquarie University, Sydney 2109, Australia; andrew.farrell@mq.edu.au

\begin{abstract}
This article explores shifting social arrangements on social media as experienced by Aboriginal and Torres Strait Islander gay, lesbian, bisexual, transgender, intersex, and queer (LGBTIQ+) peoples. These digital social assemblages are situated within a broader context of heteropatriarchy and settler colonialism in Australia and beyond. In digital spaces, multiple marginalised groups encounter dialogic engagements with their friends, followers, networks, and broader publics. The exploration of how digital discourses (in)visibilise Indigenous LGBTIQ+ diversities underline the intimate and pervasive reach of settler colonialism, and highlight distinctly queer Indigenous strategies of resistance. Through the experience of Aboriginal and Torres Strait Islander LGBTIQ+ artists, activists, and celebrities, this article demonstrates the shifting unities and disunities that shape how we come to know and understand the complexities of Indigenous LGBTIQ+ identities and experiences.
\end{abstract}

check for

updates

Citation: Farrell, Andrew. 2021. Feeling Seen: Aboriginal and Torres Strait Islander LGBTIQ+ Peoples, (In)Visibility, and Social-Media Assemblages. Genealogy 5: 57. https: / / doi.org/10.3390/ genealogy5020057

Received: 15 April 2021

Accepted: 7 June 2021

Published: 12 June 2021

Publisher's Note: MDPI stays neutral with regard to jurisdictional claims in published maps and institutional affiliations.

Copyright: (C) 2021 by the author. Licensee MDPI, Basel, Switzerland. This article is an open access article distributed under the terms and conditions of the Creative Commons Attribution (CC BY) license (https:// creativecommons.org/licenses/by/ $4.0 /)$.
Keywords: Aboriginal; Torres Strait Islander; gender; sexuality; LGBTIQ+; social media

\section{Introduction}

Social media provide a discursive landscape that enables Aboriginal and Torres Strait Islander gay, lesbian, bisexual, transgender, intersex, and queer (LGBTIQ+) peoples to be seen, heard, and understood. These positive outcomes are negotiated alongside the negative and adverse effects of social media. This article adopts the concept of "assemblages" from Deleuze and Guattari (1988) to analyse how Aboriginal and Torres Strait Islander LGBTIQ+ peoples utilise and negotiate social media to assert their lived complexities. This paper assembles a range of approaches to social media by Aboriginal and Torres Strait Islander LGBTIQ+ peoples through individuals and groups who seek to challenge, resist, and transform broader perceptions of Aboriginal and Torres Strait Islander genders and sexualities. Assemblages are also used to highlight dominant society by locating power structures in which Indigenous LGBTIQ+ peoples exist. The replication and destabilisation of settler colonialism in digital contexts negotiates the reinforcement, maintenance, and resistance to settler-colonial heteropatriarchy. Through the affordances of social media, Aboriginal and Torres Strait Islander LGBTIQ+ peoples push against material and symbolic articulations of settler-colonial logics online through the assertion of sovereign identities that render diverse Indigenous gender, sex, and sexual intersubjectivities visible.

\section{Legibility and Assemblage Thinking}

Through heteropatriarchal settler colonialism, Indigenous genders and sexualities have been violently dispossessed and forcibly assimilated into European gender, sex, and sexual orders (Driskill 2004; Picq 2020; Hodge 2015). In Australia, critical literary contributions have embedded the experiences of Indigenous women and LGBTIQ+-identified Aboriginal and Torres Strait Islander peoples (Moreton-Robinson 2000; Farrell 2017; Sullivan and Day 2019; O'Sullivan 2019; Hodge 2015). These contributions are predicated by decades of grassroots Indigenous feminist and LGBTIQ+ activism in Australia (Farrell 2021). Indigenous LGBTIQ+ critique is uniquely positioned to identify, challenge, and 
transform settler-colonial heteropatriarchy (Driskill 2004). Indigenous LGBTIQ+ critiques build on arguments that claim gender and sexual diversity across many Indigenous societies that predate European heteropatriarchy. Discourses of legibility, recognition, and representations of Indigenous gender and sexual diversities resist the centralising dominance of heteropatriarchal settler colonialism (O'Sullivan 2019). There is also growing literature that situates Indigenous peoples as being actively engaged in digital life through discourse around race, culture, gender, and sexuality (Carlson 2019; Carlson et al. 2018). This article continues to embed such complexities that are predicated by legacies of converging Indigenous and LGBTIQ+ politics and its genealogy is connected to critical academic and grassroots movements that are often overlooked, marginalised, and actively silenced and erased.

Agreements and disagreements on social media are fluid, conditional, and unstable. De Ridder (2017) argues that social media provide people with a space to negotiate material and symbolic meanings relating to sex and sexuality. These discourses shape material life while also ideologically functioning in shaping user perceptions when they make sense of the world around them. Carlson and Frazer discuss forms of social unity and disunity between Indigenous and non-Indigenous peoples online, drawing on Deleuze and Guattari's notion of "assemblage" (Frazer and Carlson 2017). Assemblages are described as a multiplicity made up of many heterogeneous terms that establish liaisons and relations across various points of difference (Frazer and Carlson 2017, p. 55). Through their use of Indigenous memes, assemblages are used to describe the ways in which social media are used to generate and sustain moments of social and political agreements that make, remake, and tether moments of social unity that contribute to anticolonial politics in Australia (Frazer and Carlson 2017, p. 1). Social-media users are positioned within formations of unity that are largely temporary and co-functioning as a symbiosis, a "sympathy" between participants. Fluctuating parameters, momentary unities, and shifting alliances are dependent on the discursive, social, cultural, and political themes present in the content shared and discussed online, and resonate with prevailing and dominant attitudes offline. These discourses include those of gender, sex, and sexual difference that shape and are shaped by assemblages that shift across social contexts.

Frazer and Carlson (2017) argued that the overtly anticolonial political standpoint that Indigenous peoples present online is often an unwelcome and uncomfortable interruption to dominant discourses across both online and offline contexts. Disagreements on topics such as race and identity often also include gender and sexuality that "are necessary components in the declaration of the self" (Robinson 2007, p. 94). As we interact online, we require a sense of other identities, beliefs, and experiences in order for us to make any judgement or decision. These interactions also "shape how we can speak of ourselves and of each other, how we understand one another and the ongoing relations between us, and how we describe and represent our 'lived realities'" (Nakata 2007, p. 199). We attempt to manage, project, reveal, and protect ourselves in these engagements. Curating our self-presentation online is then a process of internalisation where we actively construct an imagined appearance of the self, and perform a judgement of the self and our emotional response to that judgement, which Robinson (2007, p. 95) calls "cyberselfing". Carlson (2019) demonstrates how the dialogic process of cyberselfing silences Indigenous and LGBTIQ+ identity through dating apps where Aboriginal and Torres Strait Islander people are attentive to the presentation of their identities as they experience racism, abuse, fetishisation, and rejection following identification as Indigenous. A participant who identifies as both gay and Aboriginal revealed that he employed anonymity to conceal and shift the ways in which he is perceived across social media and dating apps due to his experience of racism within the gay community (Carlson 2019).

\section{Public Sphere}

What we see online is determined by a complex relationship of our interaction with digital systems embedded across the Internet. Our online activity establishes and identifies 
patterns to provide us with the most relevant content. Link sharing is one of many types of online behaviour that determine information that is regulated and directed towards us. Walker (2005) argues that link sharing has a major impact on accessibility. Our online patterns and behaviours dictate what content we ultimately see. The content that we see, like, link, and share then synthesises and narrows down the content that arguably isolates us to a vacuum of information which informs potential new information that we can choose to consume. While our perception of the Internet is underpinned by unrestricted and unregulated access to information, the result of algorithms also serves to limit and restrict what we see. There is a growing awareness of the issue of treating data as simply objective and conflating data with value (Walker 2005; Kruse et al. 2018). Data hierarchies generated on major search engines such as Google present us with a filtered lens that arguably produces relevant results. Walker (2005) calls this process "PageRanking". Prior systems that employed data indexing by other means are systematically overrun by the monopoly of data hierarchies determined by online user activity. These processes have implications for the way in which diverse content is seen and shared. It may also have a drastic impact on our opportunities to access content which prioritises communities who are already placed in the periphery of society. On online platforms, alternate standpoints are further marginalised by algorithms, which devalues them because of a lack of engagement from users. Such limitations can be challenged through, for example, an uptake in search terms "Aboriginal" in combination with "LGBTIQ+", "gay", and "queer". How such a thing materialises is subject to personal activity and increasing user assemblages that potentially constitute and maintain its visibility.

The visibility of Aboriginal and Torres Strait Islander LGBTIQ+ intersubjectivities online is dependent on the transformation of the public sphere. Kruse et al. (2018) provide empirical data on online civil communication of political issues in order to test the transferral of political discourse among social-media users across offline and online contexts. Its core theoretical underpinning questions if social-media platforms reconstitute a "public sphere", which is described as a place where private people come together as a public for the purpose of using reason to further critical knowledge that, in turn, leads to political change (Kruse et al. 2018, pp. 62-63). The potential of an accessible public sphere includes the opportunity to challenge dominant discourse, the ability to offer alternative perspectives, and author texts free of technological restrictions and institutional influence (Kruse et al. 2018). Ultimately, accessibility is limited from the outset, as not all people have Internet access or access to it in the same way. While Carlson (2016) identified that Indigenous people are taking to social media at higher rates than their non-Indigenous counterparts, there are still barriers to accessibility, including but not limited to socioeconomic disadvantages. Specific barriers for LGBTIQ+ Indigenous populations accessibility persist as gaps in quantified research.

Social media are perceived to be spaces where all people gain greater access to information, opportunities to engage, and an enhanced ability to undertake individual and collective action. Prominent Indigenous LGBTIQ+ social-media accounts have spoken against these perceived freedoms. Nayuka Gorrie, a Kurnai/Gunai, Gunditjmara, Wiradjuri, and Yorta Yorta person recounts the experiences of being intimidated by the police who visited their previous residences to inquire about their online activity. Gorrie (2018) argues that "black lives are not safe in this country. We are not safe online, we are not safe around police, and we are not safe even on our own country". Gorrie's experience is a testament to racist double standards in Australia that play out across online and offline contexts. While Australians are perceived to be imbued with freedom of speech or rather freedom of expression, as sanctioned in Australian law by the High Courts of Australia (Australian Human Rights Commission n.d.); Gorrie demonstrates that freedom of expression is not afforded to Indigenous people. This testimony highlights gaps in knowledge where current research on social-media users shows that, on average, users experienced more civil interactions offline in the context of face-to-face communication (Kruse et al. 
2018). Gorrie's experience shows that civility is afforded only to dominant society rather than to those who experience multiple intersections of oppression.

\section{Digital Platforms and Community Assemblages}

Through social media, traditional media content is mobilised to amplify the voices of LGBTIQ+ Aboriginal and Torres Strait Islander peoples. Queer and Indigenous publications, including the Star Observer and Koori Mail, have recognised Indigenous LGBTIQ+ issues and concerns through articles and special editions. One example of this includes the Star Observers NAIDOC and Black History Month issue of August 2016. Notable achievements in print media include the early work of John Newfong, a gay-identified Ngugi man, and contemporary Indigenous LGBTIQ+ journalists such as Allan Clarke, who won the Walkey award for his coverage of Indigenous affairs in 2018 (The Walkey Foundation 2018; Clarke 2015). Beyond Indigenous LGBTIQ+ journalistic contributions, their presentation of LGBTIQ+ stories and perspectives is challenging non-queer Indigenous and non-Indigenous journalists to undertake the necessary ethical and equitable concerns of LGBTIQ+ Indigenous inclusion. This has produced content where community members with little to no experience in authorship are increasingly afforded representation, authorship, and a voice in their own stories across various online platforms (Farrell 2017).

Indigenous social-media users have highlighted issues of recognition within various levels of Australia's infrastructure. The invisibility of Aboriginal and Torres Strait Islander LGBTIQ+ populations continues through the documentation and (mis)representations of Indigenous peoples in national data collection and research, which continue to exclude those who identify as gender and sexually diverse. Notable examples such as the Australian Census render categories of Indigenous, and gender and sexual diversity as unrelated, in discrete categories. The Australian Census has been criticised online as having little nuance, with statistics that ultimately fail to incorporate intersections of identities (Bonson 2016; ATSISPEP 2016). A comprehensive recognition of the diversity of these communities would show that LGBTIQ+ peoples exist within the Aboriginal and Torres Strait Islander demographic, and that Aboriginal and Torres Strait Islander peoples exist within the identified gender and sexually diverse population. Any separation and ambiguity around this overlap reflects a limited and failed knowledge, understanding, and value assigned to these groups. The identified gaps in the Census demonstrate that the Australian government is slow to include minority populations, with same-sex coupling only having been recognised since 1996 (Gray and Evans 2017). The Australian Census still purports to provide a "rich snapshot of all people living in the country", yet fails to identify the complex diversity within the country through limited taxonomies that claim who we are (abs.gov.au).

Digital platforms serve as a continued site of critical recognition across both online and offline Indigenous community spaces. Aboriginal and Torres Strait Islander organisations such as the National Aborigines and Islanders Day Observance Committee (NAIDOC) have been identified online for their lack of inclusion. The NAIDOC organisation was established in 1957 to "raise awareness in the wider community of the status of Aboriginal and Torres Strait Islander peoples" (National Aborigines and Islanders Day Observance Committee n.d.). A recent Change.org petition by Clayton Simpson-Pitt titled "NAIDOC First Peoples LGBT Award" was aimed at NAIDOC, appealing to the committee to recognise the status of LGBTIQ+ peoples across our communities. As a representative of the marginalised group, Simpson-Pitt sought to publicly engage this issue through Change.org, a website that provides social-media users the ability to produce digital petitions that they share across social media to gain support. The petition, which aims to collect 200 signatories and counting, calls for the NAIDOC committee to develop a category recognising Aboriginal LGBTIQ+ achievements in the annual NAIDOC awards ceremony. It proposes:

Our Black Indigenous LGBT Community plays a central role in many aspects of our [Indigenous communities] lives ... The overall aim of this advocacy is for a better change to our inclusiveness as a broader Indigenous community that is 
accepting and tolerant of all our people no matter who they are. (Simpson-Pitt 2019)

The continued absence of LGBTIQ+ representation in contemporary Indigenous organisations that award members of its community for social, cultural, and political progress is another active source of erasure. The petition and its effectiveness are yet to be determined by the establishment of an LGBTIQ+ category in the awards; however, the existence of the petition is indicative of critical assemblages that aim to bolster LGBTIQ+ Indigenous peoples through community support using digital platforms to address injustices and equity. It is through such assemblages that allied individuals are called to contribute to a dialogue around Indigenous identity, who also share and value the inclusion and visibility of Indigenous LGBTIQ+ peoples. Assemblages perform a crucial role in approaches that aim to heal social and cultural fractures in Aboriginal and Torres Strait Islander communities to alleviate exclusion and marginalisation.

The exclusion of LGBTIQ+ peoples in Aboriginal and Torres Strait Islander organisations is also reflected in recent developments of the National Indigenous Human Rights Awards, where a recipient of the Dr. Yunupingu Award for Human Rights, Dameyon Bonson, founder of the Indigenous LGBTIQ+ suicide prevention initiative Black Rainbow, made a public statement across digital and social media on why he was giving back his award. Bonson's challenge provoked an acknowledgement and response to antigay remarks made by one of its award-category namesakes, Anthony Mundine, who posted several anti-LGBTIQ+ statuses on social media and on television (Wade 2018). Bonson argues:

The people that run the [Human Rights] awards are pretty much standing by and not doing anything about it, so I've effectively handed back my award ... It's difficult for me to be associated with it while they still show support for Mundine through his award category ... I can't support someone so unapologetically homophobic. (Wade 2018)

A range of responses on social media followed. The online article received an outpouring of support, labelling the move "a principled stance" and questioning "why is [Bonson] giving back the award? Mundine is the disgrace". People in the comment section asked follow-up questions about whether other recipients of the Anthony Mundine Award would step up and speak out against the sports figure. Lex Wotton, a respected advocate for the Aboriginal community in Palm Island, handed back his award for courage in solidarity with Bonson stating that "I have a gay son ... Why should I keep this award when Mundine's behaviour doesn't line up to what I believe in?" (Jenkins 2018). Wotton's statement and gesture are a public display of solidarity. Launching from individual to collective forms of leadership on these intersecting issues produced a shift in political engagements across Aboriginal and LGBTIQ+ communities, signalling that Indigenous LGBTIQ+ progress should be a priority for Indigenous communities. As Simpson-Pitt identified, Aboriginal and Torres Strait Islander communities' function better with the support of their LGBTIQ+ family: our mothers, fathers, brothers, sisters, cousins, children, and kin (Simpson-Pitt 2019). These assemblages provide a blueprint of intracommunity leadership that fosters positive inclusive change that is crucially self-determined.

\section{Influence and Celebrity}

Celebrity culture has adjusted to digital spaces in ways in which individuals, celebrities, and other public figures are the subject of increasing accessibility and hypervisibility. Social-media platforms produce their own kinds of celebrities, whose influence can span local and global reach. Digital celebrities are bolstered and undone through the assemblages that form around them. McCausland (2004) argues that audiences of print media are receptive of ideas about groups of people that they have not experienced, and such is the case for celebrities who are situated outside of dominant categories of race, class, 
ethnicity, gender, sex, and sexuality. Where digital audiences meet the other, indeterminate paths occur around cultural, gender, and sexual modes of difference.

Social-media users are provided with expressive modes of communication that can be utilized to perform online interactions that compensate for the limitations of written text (Highfield and Leaver 2016). Social-media platforms enable users to use GIFs (Graphics Interchange Format) as a mode of online expression. Through GIFs, Aboriginal and Torres Strait Islander LGBTIQ+ people are embedded into everyday communication, for example, GIFs based on the television program Black Comedy, a popular Aboriginal and Torres Strait Islander sketch comedy show. Black Comedy has platformed significant mainstream representations of LGBTIQ+ Aboriginal writers and performers in sketches such as "The Tiddas", a saga based on two Indigenous gay men created by Stephen Oliver, a Kukuyalanji, Waanyi, Gangalidda, Woppaburra, Bundjalung, and Biripi gay man. While the Tiddas are hyper-exaggerated, their popularity is consolidated by public perceptions which recognise their flamboyant characteristics beyond the theatrical display. Oliver recounts public responses from a fan who thanked him for his portrayal, and said that her child felt comfort in seeing gay Indigenous representations. Oliver responds to this heartfelt moment by saying that:

Everything I do, I do it with the hope I can make people feel proud of who they are. To not believe the lies they've been told ... a part of me reverts back to being a 14-year-old boy living in fear that someone would find out his secret that he thought he had to be ashamed of. (Oliver 2017)

Oliver's characters open up conversations around shame and stigma placed onto Indigenous LGBTIQ+ people while also aiming to instil pride in identity. The characters validate Indigenous and queer worldviews, and their adaptation into online discourses through GIF's fosters expanding audiences and engages them in a continued dialogue in ways that traditional media cannot (Carlson 2019).

Torres Strait Islander and Aboriginal actor Ian Zaro, who also stars in ABC's Black Comedy, launched his acting career through social media. Zaro continues to perform his dynamic profile across multimedia platforms as an actor, comedian, writer, online viral sensation, and Dubsmash king (MGMT 2019). Social-media platforms have elevated Zaro to the status of an internet celebrity, a "DIY celebrity", differentiating from traditional celebrities in that they strategically attain fame by self-promoting, commodifying their talents, and publicising themselves to online communities (Abidin 2018). Zaro's career innovates representational practices by making accessible everyday experiences of queer Indigenous identity. Zaro blurs the lines between personal and public as he incorporates his everyday life in his content creation. Zaro's Facebook page provides a glimpse into his everyday life and experiences across the dynamic public and private spaces that he inhabits as a celebrity. Zaro often centres his identity online as a proud Torres Strait and Aboriginal gay man. This presentation is sometimes met with hostility and homophobia in his profile's comment sections. Threatening and violent comments include a post about Good Friday where Zaro posted a picture of himself in a white robe and wig, posing, and captioned "Not sure if this look is black Jesus or bootleg Beyoncé". This received numerous negative responses. Zaro responded to the negative comments saying: "I'm not out here to please everyone. If you don't like it move on 'cause imma [sic] do what I want. Like eating a big juicy fucking steak today Ps: you know where the block and delete button is."

Zaro's audiences, made up by both Indigenous and non-Indigenous fans, produce a blurring of private and public space where comment sections surface personal experiences of lateral violence and homophobia for display. Responses range from physical threats, denouncement, and exclusion from profiles of people claiming to speak on behalf of the Torres Strait Islander and Aboriginal community. One user wrote:

You unwanted ape looking human you weren't meant for this world ... you trying to do things for likes and attention but yet don't know who you are 
affecting... yeah mate you're affecting your "PEOPLE" coconut head boy pull your head out of your arse and start respecting your culture ... die soon.

The realities faced by Zaro as a publicly visible gay Aboriginal and Torres Strait Islander person reveal violent gendered and sexual norms that aim to control and gatekeep individual expressions of identity as authentically Indigenous. The fractured relationship between his followers is tempered by assemblages of support with audiences coming to his defence. Zaro's Good Friday post has approximately 693 positive responses and 204 negative responses. The prevalence of polarising and negative responses to content that employs a personal standpoint is apparent, as Zaro's Dubsmash compilations do not receive the same kind of response. These assemblages reflect a shifting political, social, and cultural landscape that both accepts and rejects representations of queer Indigeneity. When testing the boundaries of audiences, online celebrities such as Zaro emphasise critical dialogues around homophobia while revealing that social-media assemblages are often in the service of centralising racialised norms of heterosexuality and conformity to gender as a criterion in which one can acceptably identify as Indigenous. These dialogic performances within the context of social media underpin what Quinn (2016) refers to as social-media uses and gratification. Quinn refers to the intersection of uses that people have for employing social media where "gratifications sought from media are distinct from gratifications actually obtained from such use. The two are strongly correlated and continued use of a medium over time implies that gratifications sought are reinforced by gratifications obtained" (Quinn 2016, p. 62). Positive and negative reinforcement of Zaro's identity is affective to his ongoing position as a public figure as much as it broadly reflects the negotiation and resistance to settler colonial heteronormativity.

Twitter hosts a daily flow of dialogue around race, gender, and sexuality that has ongoing implications for social mobilities around Aboriginal and Torres Strait Islander LGBTIQ+ peoples. While Twitter hosts active and innovative Indigenous LGBTIQ+ profiles, the platform also has a reputation for toxic and intense racism and queerphobia, and it is accused of platforming white supremacy (Cox and Koebler 2019). Carlson (2016, 2019) argues that Indigenous peoples utilise Twitter's potential to teach, share knowledge, empathise, sympathise, and to connect with local, national, and international audiences. Unlike Facebook, Twitter's social connectivity is not confined or defined by a page or group, but are assemblages that work around tagging which can bolster Indigenous social, cultural, and political discourses. Colloquially known as "Indigenous Twitter", assemblages and coalitions of users form constellations of support that continue to perform a range of social mobilities such as promoting and embedding historical truth telling and activism that centre Indigenous interests. These allegiances practice radical formations through commenting, liking, and retweeting (sharing).

Aboriginal and Torres Strait Islander LGBTIQ+ peoples are tapping into Twitter's fast-paced social dialogue in powerful ways that assert their distinct standpoints. Broadly, across the Indigenous community on Twitter, the platform is used by Indigenous peoples to unpack and challenge dominant narratives, and take aim at the ongoing settler-colonial project. Claire Coleman, a queer identified Wirlomin Noongar woman who is also a published author of Indigenous literature, is one example of an Indigenous Twitter user who is known for her social-media activism. A review of her acclaimed speculative fiction Terra Nullius (Coleman 2017) noted that Coleman "aims to evoke empathy for her people while highlighting the legacy of Australia's violent colonial history" (Wallace 2018). Coleman's daily political and activist labour is conducted on her Twitter account. Coleman uses Twitter to commentate against the threat of white nationalism in Australia and respond to the social discourses around home grown terrorism. For example, after the 2019 terrorist attack against the Muslim community in Christchurch, New Zealand, Coleman took to Twitter to identify the dangers of white nationalism as one that seeks to purge the nation of non-White citizens and noncitizens, including the genocide of Indigenous peoples. On engaging with white nationalists in their many forms, Coleman suggests to Indigenous peoples that: 
When you debate them [white nationalists] remember this. It's not a debate between ideologies, it's a debate on whether or not Indigenous people get to live. Don't ever tell me to calm down when I face white supremacists. They want me dead. (Coleman 2019).

While embroiled in arguments on Twitter, Coleman calls upon non-Indigenous people to challenge extremist ideologies and to utilise their privileges to make a difference alongside Indigenous people fighting for their place in society. Coleman is critical of a silent majority of "white people who hate racists, fascists, and white supremacists [who] can choose whether or not to fight. We, the Indigenous people, do not have the luxury of choosing a side" (Coleman 2019).

Coleman argues that, if you are not actively antiracist online, you are complicit with colonialism as it persists in the digital terrain. Coleman's call to action includes a requirement of non-Indigenous social-media accounts to insist that they use their voice to bolster Indigenous resistance rather than placate themselves as inactive and passive consumers of these conversations. Coleman's critique offers an appeal to audiences to become more critical and aware about how whiteness functions in society, and demands audience solidarity with Indigenous peoples in the active rebuking of extremist ideas. Whether or not these appeals are effective in achieving empathic and active response from its audience needs to be undertaken through further research. Like many of the examples explored here, there is limited, minimal, and in some cases no research. The dismissal of Indigenous LGBTIQ+ experiences as critique undermines the very real impact of colonialism in the lives of Indigenous LGBTIQ+ lives. It is important for Indigenous research to acknowledge the specificities of Indigenous LGBTIQ+ people who, as Coleman, Zaro, Gorrie, and Bonson exemplify, shoulder the responsibility of intense and intersecting forms of marginalisation. Recognition of their resistance and achievements is vital to resisting and transforming settler-colonial nation states.

Discrimination, taboo, and prejudice against Aboriginal and Torres Strait Islander LGBTIQ+ peoples is actively resisted by online strategies of visibility and recognition. The interruption of limited, misinformed, and absent knowledge is met with strategies which aim to demystify barriers of understanding. Social media are used to offer an introduction to LGBTIQ+ Aboriginal and Torres Strait Islander peoples as a way to approach and transform social discourse. Media formats such as articles, videos, and podcasts impart narratives that generously provide audiences with intimate, critical, and fundamental details that ensure that the community is understood, known, and seen for all of its complexity (Davidson 2016). Delton Clark, an Indigenous transgender woman, argues that education is the key to understanding (Kesteven and Battley 2016). Clark posted a video on social media titled Like, Comment, Share (Clark 2015). She used a questions-andanswers (Q\&A) format in which social-media users were able to message questions for her to answered. Clark opens the video explaining that she hopes to educate others about the experience of being an Indigenous transgender woman. She expresses her desire to disseminate the video to her community of Mackay, North Queensland, and across regional contexts. Clark shares an honest account of the growing support that she experienced from her family and community during her transition, and the challenges that her family face in coming to terms with her identity as she transitions from male to female:

I would love for other people in [the] LGBTIQ+ community to feel exactly how I feel in a regional community; I want them to feel like I do in Mackay ... they're accepting of it and they're happy that I'm happy, but they're still wrapping their heads around it because they raised a son and raised a grandson... and now it's like 'oh my gosh, the tables have turned. (Kesteven and Battley 2016)

For Clark, respect and understanding are not only for the benefit of the community. The acknowledgement and visibility of her experience are argued to enable her to exist in her community and live as an Indigenous trans woman. Clark's strategy in authoring and publishing on social media is conscious of a society that threatens her daily survival. Social 
media is used as a buffer to grant audiences access to her and participate in a dialogue that confronts the social and political realities of Indigenous transgender people who are statistically vulnerable and at risk on a myriad of social issues. If society were more accommodating to gender, sex, and sexually diverse experiences, and dealt with race and difference without responding in fear and violence, she would not have to do this-but she does. In negotiating these relationships, assemblages of safety have also emerged, for example, a number of social groups on Facebook that centre Indigenous LGBTIQ+ identities and networks. These spaces aim to consolidate the challenges that accompany visibility (Farrell 2017). Whether these spaces provide safety is up for further investigation.

\section{Conclusions}

The examples explored in this paper demonstrate that LGBTIQ+ Aboriginal and Torres Strait Islander peoples contend with shifting social and cultural developments, and are actively responding to societal fluctuations that both accept and reject them. The Aboriginal and Torres Strait Islander LGBTIQ+ community is publicly coming out as gender and sexually diverse by presenting and performing their identities online, and are actively and passively enriching what we know about Aboriginal and Torres Strait Islander genders and sexualities. They are challenging our perception of Aboriginal and Torres Strait Islander identities beyond normative heterosexual and cisgender boundaries. Unity and disunity performed on social media through assemblages show the complexity of society's relationship with Aboriginal LGBTIQ+ peoples, and its capacity to relate to differences in gender, sexuality, culture, and race. The increasing accessibility of LGBTIQ+ Indigenous identities is brought forth by individuals and networks who negotiate and assert difference across the context of local and global communities. Indigenous LGBTIQ+ people face the suppression of their identities and seek their freedoms through social media which demonstrably amplifies their voices. Liberation is imagined and actively sought through allegiances formed through assemblages that take the form of profiles, comments, likes, friends, subscriptions, and followers, leveraged across a range of digital contexts including social media, digital news, and socially driven websites.

Funding: This research received no external funding.

Institutional Review Board Statement: Not applicable.

Informed Consent Statement: Not applicable.

Conflicts of Interest: The author declares no conflict of interest.

\section{References}

Abidin, Crystal. 2018. Internet Celebrity: Understanding Fame Online. Bingley: Emerald Publishing Limited.

ATSISPEP. 2016. Inaugural National Aboriginal and Torres Strait Islander Suicide Prevention Conference Report. Available online: https:/ / www.atsispep.sis.uwa.edu.au (accessed on 15 April 2021).

Australian Human Rights Commission. n.d. Freedom of Information, Opinion and Expression. Available online: https://www. humanrights.gov.au/freedom-information-opinion-and-expression (accessed on 30 April 2019).

Bonson, Dameyon. 2016. No Data Exists on Suicide among Gay and Trans Indigenous Australians. The Guardian. Available online: https:/ / www.theguardian.com/australia-news/2016/may/05/no-data-exists-on-suicide-among-gay-and-trans-indigenousaustralians (accessed on 30 April 2019).

Carlson, Bronwyn. 2016. 12 Deadly Indigenous Social Media Users to Follow. The Conversation. Available online: https:// theconversation.com/12-deadly-indigenous-australian-social-media-users-to-follow-66479 (accessed on 30 April 2019).

Carlson, Bronwyn. 2019. Love and hate at the Cultural Interface: Indigenous Australians and dating apps. Journal of Sociology 56: 133-50. [CrossRef]

Carlson, Bronwyn, Daniel Browning, Summer May Finlay, Allan Clarke, and Dale Husband. 2018. Deterritorialising media: Resilience and activism. Communication Research and Practice 4: 4-16. [CrossRef]

Clark, Delton. 2015. Like, Comment, Share. Available online: https:/ /www.facebook.com/delton.clark/videos/10206267013887469 (accessed on 15 April 2021).

Clarke, Allan. 2015. Here's What It's Like to Grow Up Gay and Indigenous in Australia. Buzzfeed. Available online: https: / / www.buzzfeed.com/allanclarke/these-indigenous-people-open-up-about-their-struggles-with-t\#.fjrzL09MN (accessed on 30 April 2019). 
Coleman, Claire. 2017. Terra Nullius. Sydney: Hachette Australia.

Coleman, Claire. 2019. They Want Me Dead Whether I Fight Them or Not. Meanjin. Available online: https://meanjin.com.au/blog/ they-want-me-dead-whether-i-fight-them-or-not/ (accessed on 30 April 2019).

Cox, Joseph, and Jason Koebler. 2019. Why Won't Twitter Treat White Supremacy Like ISIS? Because It Would Mean Banning Some Republican Politicians Too, Motherboard. Available online: https://motherboard.vice.com/en_us/article/a3xgq5/why-wonttwitter-treat-white-supremacy-like-isis-because-it-would-mean-banning-some-republican-politicians-too (accessed on 30 April 2019).

Davidson, Brianna. 2016. Introducing Taz. Available online: https:/ /www.sbs.com.au/feature/taz (accessed on 30 April 2019).

De Ridder, Sander. 2017. Social Media and Young People's Sexualities: Values, Norms, and Battlegrounds. Social Media + Society 3: 1-11. [CrossRef]

Deleuze, Gilles, and Félix Guattari. 1988. A Thousand Plateaus: Capitalism and Schizophrenia. London: Bloomsbury.

Driskill, Qwo-Li. 2004. Stolen From Our Bodies: First Nations Two-Spirits/Queers and the Journey to a Sovereign Erotic. Studies in American Indian Literatures 162: 50-64. [CrossRef]

Farrell, Andrew. 2017. Archiving the Aboriginal Rainbow: Building an Aboriginal LGBTIQ Portal. Australasian Journal of Information Systems 21: 1-14. [CrossRef]

Farrell, Andrew. 2021. The Rise of Black Rainbow: Queering and Indigenizing Digital Media Strategies, Resistance, and Change. In Indigenous Peoples Rise Up: The Global Ascendency of Social Media Activism. Edited by Bronwyn Carlson and Jeff Berglund. New Brunswick: Rutgers University Press.

Frazer, Ryan, and Bronwyn Carlson. 2017. Indigenous Memes and the Invention of a People. Social Media Society. Social Media Society 3: $1-12$

Gorrie, Nayuka. 2018. Black Lives Are Not Safe in This Country. What More Do White People Want? The Guardian. Available online: https:/ / www.theguardian.com/commentisfree/2018/apr/24/black-lives-are-not-safe-in-this-country-what-more-dowhite-people-want. (accessed on 30 April 2019).

Gray, Edith, and Ann Evans. 2017. Census 2016 Puts on Display the Increasing Diversity in Australians' Relationships. The Conversation. Available online: https://theconversation.com/census-2016-puts-on-display-the-increasing-diversity-in-australiansrelationships-79903 (accessed on 30 April 2019).

Highfield, Tim, and Tama Leaver. 2016. Instagrammatics and digital methods: Studying visual social media, from selfies and GIFs to memes and emoji. Communication Research and Practice 2: 47-62. [CrossRef]

Hodge, Dino. 2015. Colouring the Rainbow: Blak Queer and Trans Perspectives. Mile End: Wakefield Press.

Jenkins, Keira. 2018. Anger over Homophobia. Koori Mail 670: 4. Available online: https://aiatsis.gov.au/collection/featuredcollections/koori-mail (accessed on 30 April 2019).

Kesteven, Sophie, and Daniel Battley. 2016. Young Indigenous Transgender Woman Says Education Is Key to Developing Understanding. ABC. Available online: https://www.abc.net.au/news/2016-04-11/transgender-indigenous-woman/7316762 (accessed on 30 April 2019).

Kruse, Lisa M., Dawn R. Norris, and Jonathan R. Flinchum. 2018. Social Media as a Public Sphere? Politics on Social Media. The Sociological Quarterly 59: 62-84. [CrossRef]

McCausland, Ruth. 2004. Special Treatment-The Representation of Aboriginal and Torres Strait Islander People in the Media. Journal of Indigenous Policy 4: 84-98.

MGMT. 2019. Biography. Available online: https:/ /augustmgmt.com/talent/ian-zaro/ (accessed on 30 April 2019).

Moreton-Robinson, Aileen. 2000. Talkin' up to the White Woman: Aboriginal Women and Feminism. Brisbane: University of Queensland Press.

Nakata, Martin. 2007. Disciplining the Savages: Savaging the Disciplines. Canberra: Aboriginal Studies Press.

National Aborigines and Islanders Day Observance Committee. n.d.NAIDOC History. Available online: https://www.naidoc.org.au/ about/history (accessed on 30 April 2019).

O'Sullivan, Sandy. 2019. A lived experience of Aboriginal knowledges and perspectives: How cultural wisdom saved my life. In Practice Wisdom: Values and Interpretations. Edited by In J. Higgs. Leiden: Brill/Sense, pp. 107-12.

Oliver, Steven. 2017. Faboriginal: Steven Oliver On Being Black, Gay, Sad and Fabulous. New Matilda. Available online: https: //newmatilda.com/2017/08/30/faboriginal-steven-oliver-on-being-black-gay-sad-and-fabulous/ (accessed on 30 April 2019).

Picq, Manuela L. 2020. Decolonizing Indigenous Sexualities: Between Erasure and Resurgence. In The Oxford Handbook of Global LGBT and Sexual Diversity Politics. Edited by Michael J. Bosia, Sandra M. McEvoy and Momin Rahman. New York: Oxford University Press.

Quinn, Kelly. 2016. Why We Share: A Uses and Gratifications Approach to Privacy Regulation in Social Media Use. Journal of Broadcasting and Electronic Media 60: 61-86. [CrossRef]

Robinson, Laura. 2007. The cyberself: The selfing project goes online, symbolic interaction in the digital age. New Media and Society 9: 93-110. [CrossRef]

Simpson-Pitt, Clayton. 2019. NAIDOC First Peoples LGBT Award. Available online: https://www.change.org/p/national-naidocnaidoc-first-peoples-lgbt-award (accessed on 30 April 2019).

Sullivan, Corrinne, and Madi Day. 2019. Indigenous transmasculine Australians and sex work. Emotion, Space and Society 32: 100591. [CrossRef] 
The Walkey Foundation. 2018. Available online: https://www.walkleys.com/hit-podcast-the-teachers-pet-wins-the-2018-goldwalkley-award/ (accessed on 30 April 2019).

Wade, Matthew. 2018. Indigenous Advocate Hands Back Human Rights Award after Mundine's Homophobic Rant. Star Observer. Available online: http:/ / www.starobserver.com.au/news/national-news/indigenous-advocate-human-rights-award-mundinecomments / 166121 (accessed on 30 April 2019).

Walker, Jill. 2005. Links and power: The political economy of linking on the Web. Library Trends 53: 524-29.

Wallace, Sue. 2018. Terra Nullius, by Claire G Coleman, Hachette Australia. Available online: https://www.weeklytimesnow.com.au/ country-living/bookshelf/terra-nullius-by-claire-g-coleman-hachette-australia-rrp-2999/news-story /8d65078ceed3c6e972f3 fba6efe57ad0 (accessed on 30 April 2019). 